\title{
Two mice models for transferability of zoonotic bacteria via tick vector
}

\author{
B. SALLAY ${ }^{1 *}$, T. VACULOVÁ ${ }^{2 *}$, M. DERDÁKOVÁ ${ }^{2}$, V. RUSŇÁKOVÁ TARAGELOVÁ ${ }^{2}$, E. ŠPITALSKÁ ${ }^{1 *}$, \\ L. ŠKULTÉTY ${ }^{1}$
}

${ }^{1}$ Institute of Virology, Biomedical Research Center Slovak Academy of Sciences, Dúbravská cesta 9, 84505 Bratislava, Slovak Republic; ${ }^{2}$ Institute of Zoology, Slovak Academy of Sciences, Bratislava, Slovak Republic

\begin{abstract}
Summary. - Spotted fever and typhus-related diseases caused by rickettsiae, Lyme borreliosis induced by spirochetes from Borrelia burgdorferii sensu lato complex, and Q fever evoked by Coxiella burnetii, are important zoonoses occurring worldwide. In order to study the pathogenesis of these infections, the efficacy of vaccines from the perspective of protection against the pathogens, pathogen - pathogen interactions during co-infections or pathogen-vector-host interrelationship, a suitable animal model should be established. In this study, we evaluated two mouse models - the $\mathrm{C} 3 \mathrm{H} / \mathrm{N}$ and Balb/c strains for susceptibility to infection and ability to transmit the pathogens via tick vector and to reveal the potential interactions between various bacterial tick-borne agents. Our results indicated that the $\mathrm{C} 3 \mathrm{H} / \mathrm{N}$ and Balb/c mice are well-accepted models of B. afzelii infection. However, they are not suitable for interaction studies with $R$. helvetica since the animals did not acquire rickettsiemia and do not transmit Rickettsia sp. to feeding ticks.
\end{abstract}

Keywords: animal model; pathogen transferability; tick vector; Ixodes ricinus; Coxiella burnetii; Rickettsia helvetica; Borrelia afzelii

\section{Introduction}

Tick-borne diseases that afflict animals and humans are caused by infectious agents transmitted by tick bites. Lyme borreliosis and rickettsioses belong to the most common tick-transmitted infections (Kurtenbach et al., 2006; Parola et al., 2013). The sheep tick, Ixodes ricinus is a geographically widespread species and the most common vector for the bacterium Rickettsia helvetica and spirochetes of the Borrelia burgdorferi sensu lato (s.l.) complex including Borrelia afzelii (Rizzoli et al., 2014). In this tick also Coxiella burnetii was detected (Rehn and Radvan, 1957; Špitalská and Kocianová, 2003; Hildebrandt et al., 2011). The infection may occur during a blood meal on infected animals, and the infection is then transmitted to other mammals during the next blood meal (Arricau-Bouvery et al., 2006; Šroký et al., 2010). Therefore, the ticks are considered as important reservoirs and potential vectors of rickettsiae

*Corresponding author. E-mail: eva.spitalska@savba.sk; phone: +421-2-59302430. "Both authors equally contributed to the paper. and C. burnetii, which are transstadially and transovarially transmitted in some tick species (Daiter, 1977; Klyachko et al., 2007; Široký et al., 2010).

Ticks can even harbour more than one disease-causing agent at the same time. During life cycle, I. ricinus feeds on three different hosts. Therefore the probability of infection with different pathogens is very high (Gray, 1984). Thus, inside the tick, pathogens might interact and affect each other during the natural vector-pathogen-host cycle (Václav et al., 2011). To study the transferability of the pathogens within the tick vector-animals-cycle and pathogen - pathogen interactions during co-infections, a suitable animal model must be established. Recent studies have reported that these infections can be established in mice, depending on the genetic background of mice, the individual tick-borne species and the route of inoculation (Bechah et al., 2008; Tonetti et al., 2015). Inbred mice were used to define haplotype susceptibility and to study the pathogenesis of arthritis or carditis evoked by borrelial infection. Also, the $\mathrm{C} 3 \mathrm{H}$ mice have been employed to correlate genetic markers and development of chronic or late borrelial infection (Herrmann, 1995).

In order to shed light on the role of arthropod vectors within the pathogen circulation in natural foci, we tested 
two mouse models for Rickettsia helvetica and Borrelia afzelii infection. The specific goal was to determine the suitable animal model and figure out the transmission efficiency and potential of the interaction between bacterial pathogens during coinfection. The experiment was performed under laboratory conditions with $\mathrm{C} 3 \mathrm{H} / \mathrm{N}$ and $\mathrm{Balb} / \mathrm{c}$ mice as reservoir hosts and I. ricinus ticks as a vector.

\section{Materials and Methods}

The model host organism. Thirty-five 8-week-old pathogen-free female $\mathrm{C} 3 \mathrm{H} / \mathrm{N}$ and Balb/c mice were used and housed individually according to EU guidelines. All animal protocols were approved by the Ethics Committee of the Institute of Virology, Biomedical Research Center SAS and the State Veterinary and Food Institute of the Slovak Republic (Permit No. 292/16-221b)

Ticks. Uninfected laboratory reared I. ricinus larvae originated from the laboratory colony of the Institute of Zoology SAS, Bratislava, Slovak Republic and Institute of Parasitology, Biology Centre CAS, České Budejovice, Czech Republic were employed.

Bacterial pathogen. The CB-43 strain (Štěpánová-Tresová et al., 1999) of Borrelia afzelii grown in BSK-H media and Rickettsia helvetica (Sekeyová et al., 2012) propagated on Vero cells were studied.

Experimental design. Two mice strains, $\mathrm{C} 3 \mathrm{H} / \mathrm{N}$ and $\mathrm{Balb} / \mathrm{c}$, were used. Balb/c mice were separated into 3 groups consisting of 5 animals each. The 1 st and 2 nd groups were inoculated with $B$. afzelii and $R$. helvetica, respectively. The 3 rd group was inoculated with saline as negative control. The 2 nd experiment included 20 $\mathrm{C} 3 \mathrm{H} / \mathrm{N}$ mice which were separated into four groups with 5 mice each (1st group - mice inoculated with B. afzelii strain, 2nd group - mice inoculated with $R$. helvetica, 3rd group - mice inoculated with $B$. afzelii strain and $R$. helvetica, 4 th group - mice inoculated with saline as negative control group). Mice were injected with pathogens intraperitoneally and subcutaneously in the dorsal thoracic midline with $10^{3}$ spirochetes of CB-43 strain of B. afzelii ( $500 \mu \mathrm{l}$ of suspension per mouse) and $8 \times 10^{4} R$. helvetica ( $500 \mu \mathrm{l}$ of suspension per mouse) overall. Mice were under anesthesia when challenged with uninfected I. ricinus larvae on the dorsal side at the 2 nd and 14th day's post-infection allowing feeding. Four to 8 days later, the engorged tick larvae detached spontaneously from individual mice and were kept separately in vials with filter paper and closed by cloth. Vials were kept in a glass box at $23-26^{\circ} \mathrm{C}$ with a relative humidity of $60-80 \%$. Random samples of 10 fully engorged larvae per mouse and random samples of 10 molted nymphs per mouse were examined for the presence of pathogens, B. afzelii and R. helvetica. An ear punch biopsy was collected from each mouse with sterile scissors and tweezers at 2 weeks postinoculation and tested for the presence of pathogens. All mice were sacrificed by cardiac bleed followed by cervical dislocation under anesthesia after tick feeding. Subsequently, ear biopsies and organ samples were collected. All tissue samples were stored at $-20^{\circ} \mathrm{C}$ until further investigation.
Molecular analysis. DNA was extracted from ticks and tissues using a DNeasy Tissue Kit (Qiagen, Valencia, CA). All samples were screened using specific primers by real-time PCR for the presence of $R$. helvetica (23S rRNA) and B. burgdorferi s.l. (rrfA rrlB intergenic spacer of 5S-23S rDNA), respectively. The forward primer Bb23Sf (5'-CGAGTCTTAAAAGGGCGATTTAGT-3'), the reverse primer Bb23Sr (5'-GCTTCAGCCTGGCCATAAATAG-3') and the TaqMan probe Bb23Sp-FAM (5'-AGATGTGGTAGA CCCGAAGCCGAGTG-3') were used for the detection of $B$. afzelii (Courtney et al., 2004). The reaction mixtures contained $12.5 \mu \mathrm{l}$ of the $2 \mathrm{x}$ SuperHot Master Mix (Bioron, Ludwigshafen, Germany), $0.625 \mu \mathrm{l} \mathrm{MgCl} 2,1.8 \mu \mathrm{l}$ forward and reverse primers (final concentrations of $10 \mathrm{pM}$ of each primer), $0.5 \mu \mathrm{l}$ TaqMan probe (final concentration of $10 \mathrm{pM}$ ), 2.775 PCR water, and $5 \mu \mathrm{l}$ of the template in a total volume of $25 \mu \mathrm{l}$. Each sample was subjected to a Real-time PCR program using Bio-Rad CFX96TM Real-Time System, consisting of 3 steps: initial denaturation at $95^{\circ} \mathrm{C}$ for 2 min., followed by 39 cycles at $95^{\circ} \mathrm{C}$ for $15 \mathrm{~s}$ and $60^{\circ} \mathrm{C}$ for $1 \mathrm{~min}$. For detection of $R$. helvetica, we used the forward primer Rickhelv. $147 \mathrm{f}$ (5'-TTT GAA GGA GAC ACG GAA CAC A-3'), the reverse primer Rickhelv.211r (5'-TCC GGT ACT CAA ATC CTC ACG TA-3') and the probe Rickhelv.170p (5'-6-FAM-5'AAC CGT AGC GTA CAC TTA-TAMRA-3') (Boretti et al., 2009). The real-time PCR mixtures contained $4 \mu \mathrm{l}$ of the $5 \mathrm{x}$ HOT FIREPol Probe qPCR Mix Plus (Solis BioDyne, Tartu, Estonia), final concentrations of $100 \mathrm{nM}$ of each primer and $100 \mathrm{nM}$ of the probe, and $3 \mu \mathrm{l}$ of the template in a total volume of $20 \mu$ l. The $R$. helvetica-specific real-time PCR assay was performed using a Bio-Rad CFX96TM Real-Time System, with an initial step of $50^{\circ} \mathrm{C}$ for $2 \mathrm{~min}$ and a denaturation step at $95^{\circ} \mathrm{C}$ for 15 min, followed by 45 cycles of $95^{\circ} \mathrm{C}$ for $15 \mathrm{~s}$ and $60^{\circ} \mathrm{C}$ for $1 \mathrm{~min}$.

\section{Results and Discussion}

$\mathrm{Balb} / \mathrm{c}$ mice were used as a host for selected pathogens in the first experiment. Organ specimens from Balb/c mice and ticks feed on mice were $R$. helvetica-negative. On the other hand, infection of Balb/c mice with $B$. afzelii was successful. It was confirmed in hearts (5/5 of mice), lungs (3/5), urinary bladders $(3 / 5)$, kidney $(1 / 5)$, larvae $(40 \% ; 10 / 25)$ and molted nymphs $(52 \% ; 13 / 25)$ feeding on the infected mice.

In the 2 nd experiment, $\mathrm{C} 3 \mathrm{H} / \mathrm{N}$ mice were applied. $R$. helvetica was occasionally confirmed in ear biopsy, spleen, and urinary bladder obtained from the mice infected with both pathogens and in lung, liver, and spleen in mice infected with $R$. helvetica (Table 1). It was also found in one larva fed on $R$. helvetica infected mouse. On the other hand, B. afzelii was detected in ear biopsies, heart, lung, kidney, and urinary bladder tissues of infected $\mathrm{C} 3 \mathrm{H} / \mathrm{N}$ mice (Table 1). Larvae, which were placed on $B$. afzelii infected mice at the second day after inoculation of pathogens and molted nymphs were negative. Totally, 31\% (31/100) of larvae, which were placed on these mice at 14 th day after inoculation with pathogens 
Table 1. Borrelia afzelii and Rickettsia helvetica positivity of tissues from $\mathrm{C} 3 \mathrm{H} / \mathrm{N}$ mice

(No. of B. afzelii-positive mice / No. of R. helvetica-positive mice / total mice)

\begin{tabular}{lccc}
\hline & $\begin{array}{c}\text { B. afzelii-infected } \\
\text { mice }\end{array}$ & $\begin{array}{c}\text { R. helvetica-infected } \\
\text { mice }\end{array}$ & $\begin{array}{c}\text { B. afzelii+R. helvetica- } \\
\text { infected mice }\end{array}$ \\
\hline Ear biopsies & $5 / 0 / 5$ & $0 / 0 / 5$ & $5 / 1 / 5$ \\
Blood & $0 / 0 / 5$ & $0 / 0 / 5$ & $0 / 0 / 5$ \\
Heart & $5 / 0 / 5$ & $0 / 0 / 5$ & $5 / 0 / 5$ \\
Lung & $4 / 0 / 5$ & $0 / 1 / 5$ & $5 / 0 / 5$ \\
Liver & $0 / 0 / 5$ & $0 / 1 / 5$ & $0 / 0 / 5$ \\
Spleen & $0 / 0 / 5$ & $0 / 1 / 5$ & $0 / 1 / 5$ \\
Kidney & $2 / 0 / 5$ & $0 / 0 / 5$ & $4 / 0 / 5$ \\
Urinary bladder & $5 / 0 / 5$ & $0 / 0 / 5$ & $0 / 0 / 5$ \\
\hline
\end{tabular}

and $22 \%(22 / 100)$ of molted nymphs were positive for the presence of $B$. afzelii.

Mice have been also used as an animal model for studying C. burnetii infection. In an evaluative study of 47 strains of inbred laboratory mice, 33 were found to be resistant to infection of C. burnetii phase I Nine Mile, 10 were partially susceptible, and 4 were susceptible (Scott et al., 1987). Viable C. burnetii cells were visible in organs of the sensitive mice strains. Furthermore, these mice generated protective immune response against C. burnetii (Scott et al., 1987). From these strains, the highest mortality $(70 \%)$ was observed in the A/J strain. The BALB/c strain was reliably infected and displayed overt signs of illness, including ruffled fur and lethargy. Splenomegaly, weight loss, and seroconversion were also recorded. These characteristics could be the most reliable markers of C. burnetii infection in mice. In the case of $\mathrm{C} 3 \mathrm{H} /$ HeJ strain inoculated with C. burnetii phase I, only the half of animals were affected (Scott et al., 1987). It indicates that mouse susceptibility to infection depends on the immune machinery of each mouse strain.

In this regards, the mouse strains that are susceptible to one bacterium are likely not sensitive to another (Bechah et al., 2008). For example, BALB/c mice represent a convenient model for epidemic typhus, but it does not constitute a model for murine typhus. On the other hand, $\mathrm{C} 3 \mathrm{H} / \mathrm{HeN}$ mice are susceptible to $R$. typhi. It is also known that R. akari, $R$. conorii and $R$. sibirica are highly lethal for $\mathrm{C} 3 \mathrm{H} / \mathrm{HeJ}$ mice, but $R$. rickettsii and $R$. australis are not (Eisemann et al., 1984). $R$. helvetica did not show any pathogenic effect on Swiss mice, guinea pigs or domestic rabbits (Hajem et al., 2009).

Six pathogenic Borrelia genospecies (B. burgdorferi sensu stricto (s.s.), B. afzelii, B. garinii, B. spielmanii, B. bavariensis - originally called B. garinii OspA type 4 and B. bissettii may induce human Lyme borreliosis. Each of these genospecies is differently associated with vectors and hosts and cause distinct symptoms of the disease (Baranton et al., 1992; Canica et al., 1993; Wilske et al., 1996; Wang et al., 1997; Richter et al., 2006; Margos et al., 2009, 2013; Hubálek et al.,
2011). Rodents are the most important reservoir hosts for B.afzelii, B. burgdorferi s.s., B. spielmanii and B. bavariensis (Kurtenbach et al., 1998; Huegli et al., 2002; Richter et al., 2006). Susceptibility of laboratory mice and the course of infection depends on the genotype and age of the mice (Barthold et al., 1990). Sensitive strains of laboratory mice include SCID, C3H, and SWR mice (Barthold et al., 1990, 1999; Schaible et al., 1990; Zeidner et al., 1997). Previous studies have proven that the C57DL/6 strain, DBA/ 2J, and the BALB/c are non-sensitive to borreliae (Zeidner et al., 1997; Brown and Reiner, 1998; Ma et al., 1998; Brown et al., 2003; Ganapamo et al., 2003). However, recent studies consider BALB/c mice susceptible to B. afzelii infection (Tonetti et al., 2015; Jacquet et al., 2016).

Another significant factor determining the severity of the disease in humans and animals is pathogenicity of the infecting bacterial strain and potential co-infection with other tick-borne pathogens that may affect the transmission of the pathogen to the vectors and hosts (Nadelman et al., 1997; Schwartz et al., 1997; Thomas et al., 2001; Jacquet et al., 2016). However, the relationships of microorganisms inside the ticks and their potential role in the transmission of disease are not entirely understood. Alterations in transmission between two strains of $B$. afzelii in a vector-host experiment using $\mathrm{BalB} / \mathrm{cByJ}$ mice were already recorded with distinct courses of infection (Jacquet et al., 2016). Thus, to assess the impact of co-infection on the rate of transmission between the vectors themselves or the vector and its host, we examined the interactions of two tick-borne pathogens, R. helvetica and B. afzelii.

From the obtained results we can conclude, that $\mathrm{C} 3 \mathrm{H} / \mathrm{N}$ and $\mathrm{BALB} / \mathrm{c}$ are well-accepted mice models for $B$. afzelii that are also susceptible to C. burnetii. On the other hand, these mice strains are unsuitable for $R$. helvetica infection at an inoculation dose of $8 \times 10^{4}$ cells. These mice strains are useless for $R$. helvetica transmission and interaction studies using I. ricinus as a vector. In order to dip into this problem, more extensive interaction study on vectors co-infected with 
tick-borne microorganisms is necessary. Thus, the next step should include screening for suitable hosts and vectors. Besides conventional molecular biology methods, application of novel mass spectrometry imaging and electron microscopy techniques will be crucial, especially in analyzing molecular markers of infection. This knowledge may in future lead to improving prevention of these tick-borne diseases.

Acknowledgements. This study was financially supported by the grants of the Slovak Ministry of Education and Slovac Academy of Sciences VEGA (Nos. 2/0068/17 and 2/0119/17), the grant 21610493 of the International Visegrad Fund, and the grant 26240220096 of the Research \& Development Operational Programme funded by the ERDF.

\section{References}

Arricau-Bouvery N, Hauck Y, Bejaoui A, Frangoulidis D, Bodier CC, Souriau A, Meyer H, Neubauer H, Rodolakis A, Vergnaud G (2006): Molecular characterization of Coxiella burnetii isolates by infrequent restriction site-PCR and MLVA typing. BMC Microbiol. 6, 38. https://doi. org/10.1186/1471-2180-6-38

Baranton G, Postic D, Saint-Girons I, Boerlin P, Piffaretti JC, Assous MC, Grimont P (1992): Delineation of Borrelia burgdorferi sensu stricto, Borrelia garinii sp. nov., and group VS461 associated with Lyme borreliosis. Int. J. Systemat. Bacteriol. 42, 378-383. https://doi.org/10.1099/00207713$\underline{42-3-378}$

Barthold SW, Beck DS, Hansen GM, Terwilliger GA, Moody KD (1990): Lyme borreliosis in selected strains and ages of laboratory mice. J. Infect. Dis. 162, 133-138. https://doi. org/10.1093/infdis/162.1.133

Barthold SW (1999): Specificity of infection-induced immunity among Borrelia burgdorferi sensu lato species. Infect. Immun. 67, 36-42.

Bechah Y, Capo Ch, Mege JL, Raoult D (2008): Rickettsial diseases: from Rickettsia-arthropod relationships to pathophysiology and animal models. Future Microbiol. 3, 223-236. https://doi.org/10.2217/17460913.3.2.223

Bewley R (2013): Animal models of Q fever (Coxiella burnetii). Comp. Med. 63, 469-476.

Boretti FS, Perreten A, Meli ML, Cattori V, Willi B, Wengi N, Hornok S, Honegger H, Hegglin D, Woelfel R, Reusch CE, Lutz H, Hofmann-Lehmann R (2009): Molecular investigations of Rickettsia helvetica Infection in dogs, foxes, humans, and Ixodes ticks. Appl. Environment. Microbiol. 75, 3230-3237. https://doi.org/10.1128/AEM.00220-09

Brown CR, Reiner SL (1998): Activation of natural killer cells in arthritis susceptible but not arthritis-resistant mouse strain following Borrelia burgdorferi infection. Infect. Immun. 66, 5208-5214.

Brown CR, Blaho VA, Loiacono CM (2003): Susceptibility to experimental Lyme arthritis correlates with $\mathrm{KC}$ and monocyte chemoattractant protein-1 production in joints and requires neutrophil recruitment via CXCR2.
J. Immunol. 171, 893-901. https://doi.org/10.4049/ jimmunol.171.2.893

Canica MM, Nato F, du Merle L, Mazie JC, Baranton G, Postic D (1993): Monoclonal antibodies for identification of Borrelia afzelii sp. nov. associated with late cutaneous manifestations of Lyme borreliosis. Scand. J. Infect. Dis. 25, 441-448. https://doi.org/10.3109/00365549309008525

Courtney JW, Kostelnik LM, Zeidner NS, Massung RF (2004): Multiplex real-time PCR for detection of Anaplasma phagocytophilum and Borrelia burgdorferi. J. Clin. Microbiol. 42, 3164-3168. https://doi.org/10.1128/ LCM.42.7.3164-3168.2004

Daiter AB (1977): Transovarial and transspermal transmission of Coxiella burneti by the tick Hyalomma asiaticum and its role in the ecology of Q-rickettsiosis. Parazitologia 11, 403-411.

Eisemann CS, Nypaver MJ, Osterman JV (1984): Susceptibility of inbred mice to rickettsiae of the spotted fever group. Infect. Immun. 43, 143-148.

Feng HM, Wen J, Walker DH (1993) Rickettsia australis infection: a murine model of a highly invasive vasculopathic rickettsiosis. Am. J. Pathol. 142, 1471-1482.

Ganapamo F, Denis VA, Philips MT (2003): Differential acquired immune responsiveness to bacterial lipoproteins in Lyme disease-resistant and susceptible mouse strain. Eur. J. Immunol. 33, 1934-1940. https://doi.org/10.1002/ eji. 200323655

Gray JS (1984): Studies on the dynamics of active populations of the sheep tick, Ixodes ricinus L. in Co, Wicklow, Ireland. Acarologia 2, 167-178.

Hajem N, Weintraub A, Nimtz M, Romling U, Pahlson C (2009): A study of the antigenicity of Rickettsia helvetica proteins using two-dimensional gel electrophoresis. APMIS 117, 253-262. https://doi.org/10.1111/j.1600-0463 $.2009 .02435 . \mathrm{x}$

Herrmann JL (1995): Animal models and Lyme Disease. Clin. Microbiol. Infect. 1, 72-73. https://doi.org/10.1111/ j.1469-0691.1995.tb00448.x

Hildebrandt A, Straube E, Neubauer H, Schmoock G (2011): Coxiella burnetii and coinfections in Ixodes ricinus ticks in Central Germany. Vector-Borne Zoonot. Dis. 11, 1205-1207. https://doi.org/10.1089/vbz.2010.0180

Hubálek Z, Rudolf I (2011): Microbial zoonoses and sapronoses. Springer, Netherlands, p. 457. https://doi.org/10.1007/97890-481-9657-9

Jacquet M, Margos G, Fingerle V, Voordouw MJ (2016): Comparison of the lifetime host-to-tick transmission between two strains of the Lyme disease pathogen Borrelia afzelii. Parasite Vector 9, 645. https://doi.org/10.1186/s13071-016-1929-Z

Huegli D, Hu CM, Humair P-F, Wilske B, Gern L (2002): Apodemus species mice are reservoir hosts of Borrelia garinii OspA serotype 4 in Switzerland. J. Clin. Microbiol. 40, 4735-4737. https://doi.org/10.1128/JCM.40.12.4735-4737.2002

Klyachko O, Stein BD, Grindle N, Clay K, Fuqua C (2007): Localization and visualization of a coxiella-type symbiont within the lone star tick, Amblyomma americanum. Appl. Environ. Microbiol. 73, 6584-6594. https://doi. org/10.1128/AEM.00537-07 
Kurtenbach K, Peacey M, Rijpkema SG, Hoodless AN, Nuttall PA, Randolph SE (1998): Differential transmission of the genospecies of Borrelia burgdorferi sensu lato by game birds and small rodents in England. Appl. Environ. Microbiol. 64, 1169-1174.

Kurtenbach K, Hanincová K, Tsao JI, Margos G, Fish D, Ogden NH (2006): Fundamental processes in the evolutionary ecology of Lyme borreliosis. Nat. Rev. Microbiol. 4, 660-669. https://doi.org/10.1038/nrmicro1475

Ma Y, Seiler KP, Eichwald EJ, Weis JH, Teuscher C, Weis JJ (1998): Distinct characteristics of resistence to Borrelia burgdorferi-induced arthritis in C57BL/6N mice. Infect. Immun. 66, 161-168.

Margos G, Vollmer SA, Cornet M, Garnier M, Fingerle V, Wilske B, Bormane A (2009): A new Borrelia species defined by multilocus sequence analysis of housekeeping genes. Appl. Environ. Microbiol. 75, 5410-5416. https://doi. org/10.1128/AEM.00116-09

Margos G, Wilske B, Sing A,Hizo-Teufel C, Cao WCh, Chu CH, Scholz H, Straubinger RK, Fingerle V (2013): Borrelia bavariensis sp. nov. is widely distributed in Europe and Asia. Int. J. System. Evol. Microbiol. 63, 4284-4288. https://doi.org/10.1099/ijs.0.052001-0

Nadelman RB, Horowitz HW, Hsieh TCH, Wu JM, Aguero-Rosenfeld ME, Schwartz I, Nowakowski J, Varde S, Wormser GP (1997): Simultaneous Human Granulocytic Ehrlichiosis and Lyme Borreliosis. New Engl. J. Med. 337, 27-30. $\underline{\text { ht- }}$ tps://doi.org/10.1056/NEJM199707033370105

Parola P, Paddock CHD, Socolovschi C, Labruna MB, Mediannikov O, Kernif T, Abdad MY, Stenos J, Bitam I, Fournier PE, Raoult D (2013): Update on tick-borne rickettsioses around the world: a Geographic approach. Clin. Microbiol. Rev. 4, 657-702. https://doi.org/10.1128/CMR.00032-13

Rehn F, Radvan R (1957): Isolation of Coxiella burnetii from the tick Ixodes ricinus. Cesk. Epidemiol. Mikrobiol. Imunol. 6, 85-88.

Richter D, Postic D, Sertour N, Livey I, Matuschka FR, Baranton G (2006): Delineation of Borrelia burgdorferi sensu lato species by multilocus sequence analysis and confirmation of the delineation of Borrelia spielmanii sp. nov. Int. J. Systemat. Evol. Microbiol. 56, 873-881. https://doi. org/10.1099/ijs.0.64050-0

Rizzoli A, Silaghi C, Obiegala A, Rudolf I, Hubálek Z, Földvári G, Plantard O, Taussat MV, Bonnet S, Špitalská E, Kazimírová $M$ (2014): Ixodes ricinus and its transmitted pathogens in urban and peri-urban areas in Europe: new hazards and relevance for public health. Front. Public Health 2, 251. https://doi.org/10.3389/fpubh.2014.00251

Řeháček J, Kaaserer B, Urvolgyi J, Lukáčová M, E. Kováčová, Kocianová E (1994): Isolation of Coxiella burnetii and of an unknown rickettsial organism from Ixodes ricinus ticks collected in Austria. Eur. J. Epidemiol. 10, 719-723. https://doi.org/10.1007/BF01719288

Scott GH, Williams JC, Stephenson EH (1987): Animal models in $\mathrm{Q}$ fever: pathological responses of inbred mice to phase I Coxiella burnetii. J. Gen. Microbiol. 133, 691-700. https://doi.org/10.1099/00221287-133-3-691

Sekeyová Z, Mediannikov O, Subramanian G, Kowalczewska M, Quevedo-Diaz M, Kocianova E, Raoult D (2012): Isolation of Rickettsia helvetica from ticks in Slovakia. Acta Virol. 56, 247-252. https://doi.org/10.4149/av 201203247

Schaible UE, Gay S, Museteanu C, Kramer MD, Zimmer G, Eichmann K, Museteanu U, Simon MM (1990): Lyme borreliosis in the severe combined immunodeficiency (scid) mouse manifests predominantly in the joints, heart, and liver. Am. J. Pathol. 137, 811-820.

Schwartz I, Varde S, Nadelman RB, Wormser GP, Fish D (1997): Inhibition of efficient polymerase chain reaction amplification of Borrelia burgdorferi DNA in blood-fed ticks. Am. J. Trop. Medic. Hyg. 56, 339-342. https://doi. org/10.4269/ajtmh.1997.56.339

Široký P, Kubelová M, Modrý D, Erhart J, Literák I, Špitalská E, Kocianová E (2010): Tortoise tick Hyalomma aegyptium as long term carrier of $\mathrm{Q}$ fever agent Coxiella burnetiievidence from experimental infection. Parasitol. Res. 107, 1515-1520. https://doi.org/10.1007/s00436-010-2037-1

Špitalská E, Kocianová E (2003): Detection of Coxiella burnetii in ticks collected in Slovakia and Hungary. Eur. J. Epidemiol. 18, 263-266. https://doi.org/10.1023/A:1023330222657

Štěpánová-Tresová G, Kopecký J, Kuthejlová M (1999): Identification of Borrelia burgdorferi sensu stricto, Borrelia garinii and Borrelia afzelii in Ixodes ricinus ticks from Southern Bohemia using monoclonal antibodies. Zentralbl. Bakteriol. 289, 797-806. https://doi.org/10.1016/ S0934-8840(00)80005-5

Thomas V, Anguita J, Barthold SW, Fikrig E (2001): Coinfection with Borrelia burgdorferi and the agent of human granulocytic ehrlichiosis alters murine immune responses, pathogen burden, and severity of Lyme arthritis. Infect. Immun. 69, 3359-3371. https://doi.org/10.1128/ IAI.69.5.3359-3371.2001

Tonetti N, Voordouw MJ, Durand J, Monnier S, Gern L (2015): Genetic variation in transmission success of the Lyme borreliosis pathogen Borrelia afzelii. Ticks Tick-Borne Dis. 6, 334-343. https://doi.org/10.1016/j.ttbdis.2015.02.007

Václav R, Ficová M, Prokop P, Betáková T (2011): Associations between coinfection prevalence of Borrelia lusitaniae, Anaplasma sp., and Rickettsia sp. in hard ticks feeding on reptile hosts. Microbial Ecol. 2, 245-253. https://doi. org/10.1007/s00248-010-9736-0

Zeidner N, Mbow LM, Dolan M, Massung R, Baca E, Piesman J (1997): Effects of Ixodes scapularis and Borrelia burgdorferi on modulation of the host immune response: Induction of a $\mathrm{TH} 2$ cytokine response in Lyme diseasesusceptible $(\mathrm{C} 3 \mathrm{H} / \mathrm{HeJ})$ mice but not in disease resistant (BALB/c) mice. Infect. Immun. 65, 3100-3106.

Wang G, van Dam AP, Le Fleche A, Postic D, Peter O, Baranton G, de Boer R, Spanjaard L, Dankert J (1997): Genetic and phenotypic analysis of Borrelia valaisiana sp. nov. (Borrelia genomic groups V5116 and M19). Int. J. System. Evol. Microbiol. 47, 926-932.

Wilske B, Bush U, Eiffert H, Fingerle V, Pfister HV, Rössler D, PreacMursic V (1996): Diversity of OspA and OspC among cerebrospinal fluid isolates of Borrelia burgdorferi sensu lato from patients with neuroborreliosis in Germany. Med. Microbiol. Immunol. 184, 195-201. https://doi. org/10.1007/BF02456135 